\title{
Quantification and monetary valuation of urban ecosystem services in Munich, Germany
}

\begin{abstract}
Urban green spaces provide ecosystem services that can be used by the local population. The valuation of these ecosystem services in urban areas gives information for stakeholders and decision-makers to improve urban planning processes. In addition, this information can be used to provide a better understanding of how urban green spaces should be managed. In this study, we quantify and monetize four ecosystem services (carbon sequestration and storage, air pollution removal, runoff reduction, groundwater recharge) provided by the urban green space of Schlosspark Nymphenburg in Munich, Germany. We classify four different land cover types (tree, grass/herbaceous, water, impervious) to calculate different amounts of ecosystem services according to the land cover type. In addition, we quantify the maintenance costs which this urban green space causes to the city of Munich. The interpretation, communication and risks of valuations studies are discussed.
\end{abstract}

Keywords: ecosystem services, monetization, valuation, urban, green space, Germany, Munich

\section{Introduction}

Discussion and research about the concept of ecosystem services intensified during the 1990s. Important publications during this time started a broad discussion in many scientific disciplines (e.g. Costanza et al. 1997; Daily 1997). BoLUND/HunHAMMAR (1999) transferred this concept to urban areas. The Millennium Ecosystem Assessment (MA) defines ecosystem services as the benefits people obtain from ecosystems. "These include provisioning, regulating, and cultural services that directly affect people and the supporting services needed to maintain other services" (Millenium Ecosystem Assessment $2005,40)$. In recent years there has been an extensive discussion about classification systems (DE Groot et al. 2002; TEEB 2010) and the definition of the term service (BOYD/BANZHAF 2007; Fisher et al. 2009). The ongoing debate tries to differentiate between ecological terms like process and function and more economical/sociocultural terms like service, benefit and (economic) value. Ecosystem service research is about frameworks for valuation (WAINGER/MAZOTTA 2011; Muradian 2013), perceptions by local population (JIM/CHEN 2006), application of indicators (DoBBs et al. 2011) and benefits and limitations of the concept in policy and decision making (BOISVERT et al. 2013; GóMEZ-BAGGETHUN et al. 2013; HAUCK et al. 2013).
Besides a qualitative assessment some services can be quantified in physical measurement units. In addition, valuing can lead to a monetization of specific ecosystem services (monetary measurement units). An important issue when choosing a valuation technique is the moral and ethical aspects of the concept. LUCK et al. (2012) develop several categories of ethical problems that have to be considered when using the ecosystem service concept, such as anthropocentric framing, economic metaphor, commodification and changes in motivations.

Traditionally, the economic valuation of environmental goods is done by environmental economists who try to internalize externalities (Perman 2003; Siebert 2008). Farley (2012) demonstrates recent influences to environmental economics caused by the concept of ecosystem services. Within the interdisciplinary theoretical framework of ecological economics (COSTANZA et al. 2001; Rogall 2008) the term green accounting summarizes different approaches from different disciplines of measuring, valuing and monetizing environmental resources. One of the important steps in the evolution of valuing ecosystem services is the international initiative The Economics of Ecosystems and Biodiversity (TEEB). This initative gives an overview about theories and definitions and categorizes methods for monetizing ecosystem services (TEEB 2010). 
TEEB lists as the main methods for valuing ecosystem services the direct market valuation methods (market price-based, cost-based, production function-based), the revealed preference methods (travel cost method, hedonic pricing), the stated preference methods (contingent valuation, choice modeling, group valuation) and benefit transfer methods (transferring an existing valuation estimate from a similar ecosystem).

This paper analyzes and monetizes the annual flow of specified ecosystem services of an urban green space in Munich, compared to a situation where the green space does not exist. The estimated values are compared to the maintenance costs which this urban green space causes to the city of Munich, and opportunity costs will be discussed. In addition, study results provide information about the potentials of different urban land cover types to create ecosystem services.

\section{Methods}

\section{Study Area}

The urban green space surveyed in this study is the Schlosspark Nymphenburg. The location of Schlosspark Nymphenburg is in the central urban area of Munich, Germany's 3rd largest city (Bayerische Vermessungsverwaltung 2013). Schlosspark Nymphenburg was established in the 17th century when aristocracy used the park for their amusement. The park was transformed several times, from a hunting area to a French formal garden, then to an English landscape garden. Today it is a protected historical monument. Visitors can only enter the park during daytime (the park is surrounded by a wall) and have to follow several rules (no bicycling, no dogs, stay on the park ways). Because of this long history as a protected space, it is an important and unusual ecological resource in an urban area. Therefore it is part of a European network of protected areas (Natura 2000) and serves as a habitat for several endangered species (Bayerische Forstverwaltung 2012).

Fig. 1 shows the Schlosspark Nymphenburg with its surrounding area. We classify four different land cover types (tree, grass/herbaceous, water, impervious) to calculate different amounts of ecosystem services according to the land cover type. This general classification system is commonly used in urban areas (e.g. NowAK/ GREENFIELD 2012), and a more detailed classi- fication would be very difficult for an economic valuation. To classify the area, we use digital orthophotos (20 cm resolution) (Bayerische Vermessungsverwaltung 2012), local expert knowledge and site inspections. The area size of different land cover types in Schlosspark Nymphenburg is shown in Tab. 1. The whole area is about $1597235 \mathrm{~m}^{2}$. The largest land cover type is tree with $1198645 \mathrm{~m}^{2}$.

Tab. 1: Area of land cover types in Schlosspark Nymphenburg

\begin{tabular}{lr} 
Land Cover Type & Area $\left(\mathrm{m}^{2}\right)$ \\
\hline Tree & 1198645 \\
Grass/Herbaceous & 234337 \\
Water & 132519 \\
Impervious & 31735 \\
\hline Total & 1597235 \\
\hline
\end{tabular}

Source: own compilation

\section{Valuation methods (data and estimation)}

Carbon sequestration and storage. Carbon sequestration and storage is an important factor in mitigation strategies related to climate change. Ecosystems contribute to this by limiting greenhouse gases. During the process of photosynthesis plants sequester carbon dioxide $\left(\mathrm{CO}_{2}\right)$ from the atmosphere and store carbon in their biomass. The importance of forests as a global carbon sink has been intensively studied in the past (e. g. BuRSCHEL 1995).

A review of literature about carbon storage for mixed forests in Germany and urban trees in Germany, UK and the USA is shown in Tab. 2.

Tab. 2: Case studies with amounts for carbon storage for urban trees or forests in Germany

\begin{tabular}{llc} 
Study Area & Author & $\begin{array}{c}\text { Amount } \\
\left(\mathrm{kg} \mathrm{C} / \mathrm{m}^{2}\right)\end{array}$ \\
\hline Forest Germany & $\begin{array}{l}\text { DIETER/ELSASSER } \\
(2002)\end{array}$ & 10.38 \\
Urban Trees USA & $\begin{array}{l}\text { NowAK/CRANE } \\
(2002)\end{array}$ & 9.25 \\
$\begin{array}{l}\text { Forest Nordrhein- } \\
\text { Westfalen (Germany) }\end{array}$ & $\begin{array}{l}\text { SCHRÖDER et al. } \\
(2009)\end{array}$ & 6.70 \\
$\begin{array}{l}\text { Urban Trees Leicester } \\
\text { (UK) }\end{array}$ & $\begin{array}{l}\text { DAVIES et al. } \\
(2011)\end{array}$ & 28.86 \\
$\begin{array}{l}\text { Urban Trees Leipzig } \\
\text { (Germany) }\end{array}$ & $\begin{array}{l}\text { STROHBACH/HAASE } \\
(2012)\end{array}$ & 7.57 \\
\hline
\end{tabular}

Source: own compilation 
Differences occur because of the climatic and forest conditions of the study areas and different methods for calculating the amount of carbon stored in the biomass of the trees (e.g. aboveground biomass versus below-ground biomass: Coarse wood, small wood, needles, roots etc.). The carbon amounts are per square meter canopy cover and for mixed forests (instead of evergreen or deciduous forests).
We use the results of StROHBACH/HAASE (2012) for benefit transfer. This study is a good approximation for the Schlosspark Nymphenburg (land cover type: Tree) because it surveys a mixed forest in a German urban area with similar climatic conditions. Because Strohbach/HaASE (2012) do not calculate below-ground biomass, we add below-ground carbon by using a below-ground to above-ground ratio of $18 \%$ from

Fig. 1: Land cover types of Schlosspark Nymphenburg

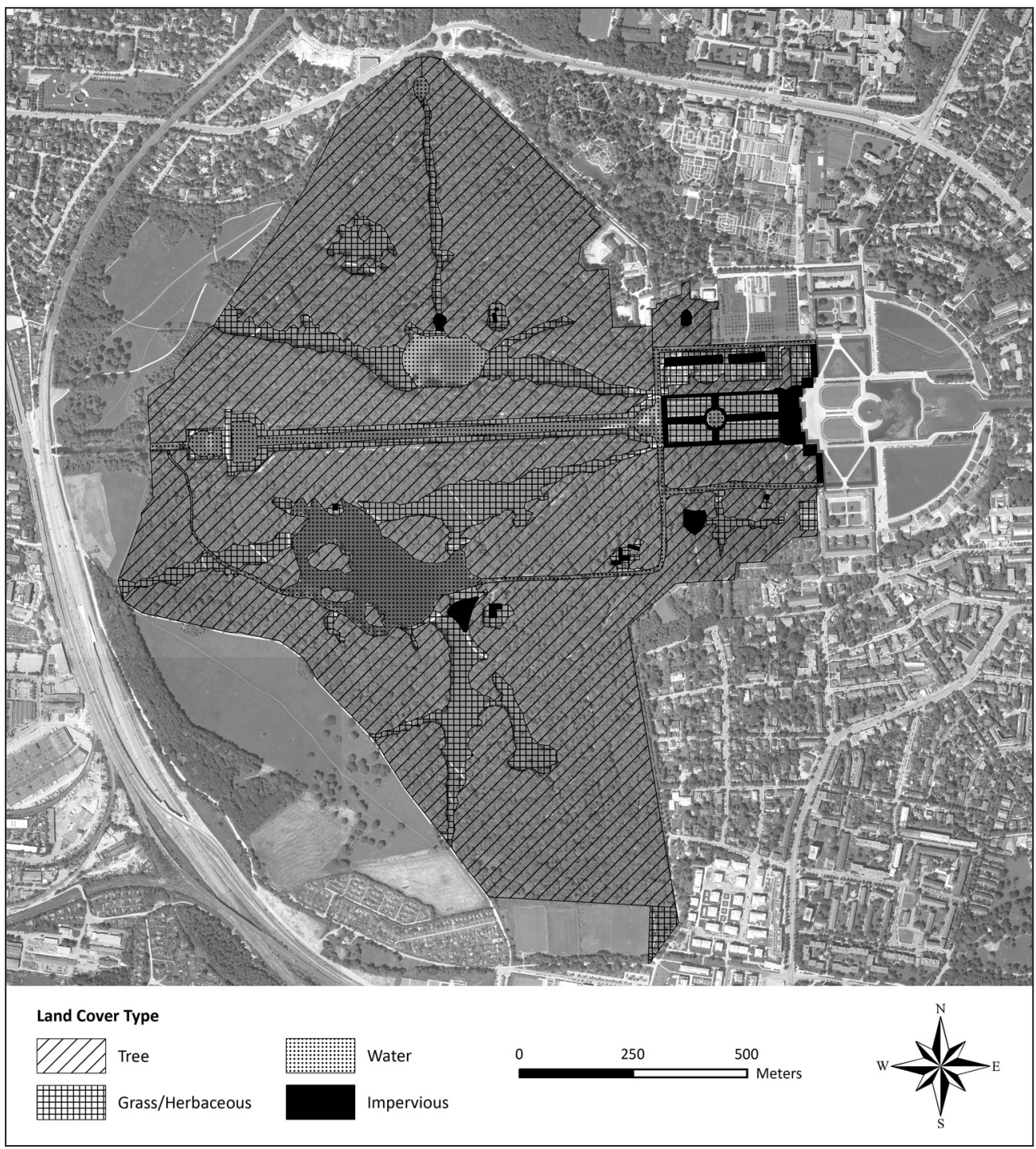

Source: map based on Bayerische Vermessungsverwaltung 2012 
Dieter/ElsAsSER (2002) $\left(7.57 \mathrm{~kg} \mathrm{C} / \mathrm{m}^{2} \times 1.18=\right.$ $\left.8.93 \mathrm{~kg} \mathrm{C} / \mathrm{m}^{2}\right)$.

There is not much literature about carbon stored in grass or shrubs. Results differ because of different vegetation structures and different kinds of maintenance. For land cover type grass/herbaceous we use the amount from DAVIES et al. (2011). They calculate $0.15 \mathrm{~kg} \mathrm{C} / \mathrm{m}^{2}$ for public herbaceous vegetation with large and infrequently mowed grass areas in an urban environment.

Carbon sequestration describes the sequestration of carbon by plants within a specific period of time (e. g. per year). Growing forests have a positive net annual carbon sequestration until the forest matures and rates can become negative. NOWAK/CRANE (2002) calculate for urban forests in ten US cities an average of $0.2 \mathrm{kgC} / \mathrm{m}^{2} / \mathrm{yr}$. We use this amount as an approximation for land cover type tree in the Schlosspark Nymphenburg in Munich. It is not only the average for US cities but NOWAK/CRANE (2002) calculate this amount for cities (e.g. Philadelphia) within the same class as Munich regarding the Köppen-Geiger climate classification (warm temperate, fully humid) (KOTTEK et al. 2006).

Several case studies that report monetary values for carbon dioxide $\left(€ / \mathrm{tCO}_{2}\right)$ are shown in Tab. 3. Currency conversions are done by using purchasing power parity rates from World Bank (2014) (0.79 units for Germany) and the atomic mass equation for converting from carbon values to carbon dioxide values $\left(1 \mathrm{kgC} \triangleq 3.67 \mathrm{kgCO}_{2}\right)$.
The European Union Emissions Trading Scheme (EU ETS) is one of the largest and most important certificate trading systems for $\mathrm{CO}_{2}$ certificates. Because of current issues with the system in phase 3 (e.g. over-allocation), we calculate an average value for one certificate in phase 2 (2008-2012) using weekly values $\left(x_{i}\right)$ at the Energy Exchange Austria (EXAA) (2014):

$$
\bar{x}=\frac{\sum_{i=1}^{n} x_{i}}{n}=17,14 € / \mathrm{tCO}_{2}
$$

Amount multiplied by value equals the monetized ecosystem service $(E S)$. According to this, the valuation model for carbon storage is:

$$
\frac{C S t o_{i} \times S_{i}}{10^{3}} \times k_{\mathrm{P}} \times V_{\mathrm{CO}_{2}}=E S_{\mathrm{CSto} i}
$$

where $\mathrm{CSto}_{i}$ is the amount of stored carbon per square meter $\left(\mathrm{kgC} / \mathrm{m}^{2}\right)$ and land cover type $i ; S_{i}$ is the area $\left(\mathrm{m}^{2}\right)$ of land cover type $i$; $k_{\mathrm{P}}$ is constant for the conversion from the amount of $\mathrm{CO}_{2}$ in the atmosphere to the amount of carbon stored in the biomass during photosynthesis; and $V_{\mathrm{CO}_{2}}$ is the value of one ton of $\mathrm{CO}_{2}\left(€ / \mathrm{tCO}_{2}\right)$.

A similar valuation model is used for carbon sequestration per year $(C S e q)\left(\mathrm{kgC} / \mathrm{m}^{2} / \mathrm{yr}\right)$ and land cover type tree $(T)$ :

$$
\frac{C S e q \times S_{T}}{10^{3}} \times k_{\mathrm{P}} \times V_{\mathrm{CO}_{2}}=E S_{\mathrm{CSeq} T}
$$

Air pollution removal. Air pollution removal describes the ability of ecosystems to improve air

\begin{tabular}{|c|c|c|}
\hline Source/Type & Author & Value $\left(€ / \mathrm{tCO}_{2}\right)$ \\
\hline Voluntary Chicago Climate Exchange & JENKINS et al. (2010) & 3.32 \\
\hline Marginal Social Damage Approach & $\begin{array}{l}\text { ATKINSON/GUNDIMEDA (2006), } \\
\text { GuNDIMEDA et al. (2007) }\end{array}$ & 4.30 \\
\hline Marginal Social Cost & NOWAK/CRANE (2002) & 4.37 \\
\hline Social Cost of Carbon & MCPHERson et al. (2011) & 5.81 \\
\hline IPCC 4th AR: Social Cost of Carbon & JENKINS et al. (2010) & 11.85 \\
\hline Social Costs & MilLwARD/SABIR (2011) & 13.04 \\
\hline Finnish Carbon Tax for Fossil Fuels & MATERO/SAASTAMOINEN (2007) & 17.10 \\
\hline Lieberman-Warner Climate Change Bill & JENKINS et al. (2010) & 19.75 \\
\hline EU Emissions Trading Scheme (EU ETS) & JENKINS et al. (2010) & 27.65 \\
\hline Carbon Tax by the Swedish Government & JIM/CHEN (2009), WANG et al. (2010) & 32.27 \\
\hline Costs to Society & VANDERMEULEN et al. (2011) & 50.00 \\
\hline
\end{tabular}
quality. Air pollutants affect human health and

Tab. 3: Case studies with values for carbon dioxide

Source: own compilation 
cause diseases such as respiratory diseases and lung cancer which decrease quality of life (POPE et al. 2004). These health effects create economic costs like medical treatment and lost productivity. In German urban areas air pollution is still an important issue because pollution levels remain high due to emissions by traffic, industry and households (Umweltbundesamt 2013).

Trees remove gaseous pollutants (e. g. sulfur dioxide, ozone) by uptake via leaf stomata (SмITH 1990), and particulate matter (e.g. $\mathrm{PM}_{2.5}, \mathrm{PM}_{10}$ ) can be captured upon plant surfaces by dry deposition (NowAK et al. 2013). Tab. 4 shows case studies which calculate amounts $\left(\mathrm{g} / \mathrm{m}^{2} / \mathrm{yr}\right)$ for air pollution removal in a specific study area. Different methods of calculation, local climate (e.g. length of growing season) and local pol- lution concentrations lead to differences in estimated results. Analog to this, Tab. 5 gives an overview about monetary values $(€ \mathrm{t})$ for six major air pollutants $\left(\mathrm{CO}, \mathrm{NO}_{2}, \mathrm{O}_{3}, \mathrm{SO}_{2}, \mathrm{PM}_{10}\right.$, $\mathrm{PM}_{2.5}$ ) used in various case studies. These are estimates of the social costs that one ton of the pollutant causes. Conversions from US and Chinese currencies are done by using purchasing power parity rates from World Bank (2014) (0.79 units for Germany; 3.51 units for China). Purchasing power parity rates for currency conversions are used throughout this study.

To calculate air pollution removal for Schlosspark Nymphenburg, the i-Tree Eco model is used (NowAK et al. 2006). i-Tree Eco is a software for valuing ecosystem services developed by the USDA Forest Service. A range of input

Tab. 4: Case studies with amounts for air pollution removal

\begin{tabular}{|c|c|c|c|c|c|c|c|}
\hline \multirow[b]{2}{*}{ Study Area and Type } & \multirow[b]{2}{*}{ Author } & \multicolumn{6}{|c|}{ Amount $\left(\mathrm{g} / \mathrm{m}^{2} / \mathrm{yr}\right)$} \\
\hline & & $\mathrm{CO}$ & $\mathrm{NO}_{2}$ & $\mathrm{O}_{3}$ & $\mathrm{SO}_{2}$ & $\mathrm{PM}_{10}$ & $\mathrm{PM}_{2.5}$ \\
\hline Boston (USA), Urban Trees & NowAK et al. (2006) & 0.30 & 2.10 & 3.80 & 1.10 & 2.80 & - \\
\hline Santiago (Chile), Urban Trees & EsCOBEDO et al. (2008) & - & - & - & - & 7.40 & - \\
\hline Santiago (Chile), Grass & EsCOBEDO et al. (2008) & - & - & - & - & 1.70 & - \\
\hline $\begin{array}{l}\text { Guangzhou (China), Urban Trees } \\
\text { in Residential Area }\end{array}$ & JIM/CHEN (2008) & - & 2.53 & - & 3.06 & - & - \\
\hline Santiago (Chile), Urban Trees & EsCOBEDO/NOWAK (2009) & 0.40 & 1.20 & 2.80 & 0.60 & 7.40 & - \\
\hline Lanzhou (China), Urban Trees & JIM/CHEN (2009) & - & - & - & 17.10 & - & - \\
\hline London (UK), Urban Trees, Flux Model & TALLIS et al. (2011) & - & - & - & - & 2.73 & - \\
\hline $\begin{array}{l}\text { London (UK), Urban Trees, Tiwary } \\
\text { Approach }\end{array}$ & TALLIS et al. (2011) & - & - & - & - & 5.85 & - \\
\hline $\begin{array}{l}\text { National Park near Mexico City } \\
\text { (Mexico), Fir Forest }\end{array}$ & $\begin{array}{l}\text { BAUMGARDNER et al. } \\
(2012)\end{array}$ & 0.02 & 0.07 & 1.97 & 0.23 & 7.13 & - \\
\hline
\end{tabular}

Source: own compilation

Tab. 5: Case studies with values for air pollution removal

\begin{tabular}{|c|c|c|c|c|c|c|c|}
\hline \multirow[b]{2}{*}{ Study Area } & \multirow[b]{2}{*}{ Author } & \multicolumn{6}{|c|}{ Value $(€ / \mathrm{t})$} \\
\hline & & $\mathrm{CO}$ & $\mathrm{NO}_{2}$ & $\mathrm{O}_{3}$ & $\mathrm{SO}_{2}$ & $\mathrm{PM}_{10}$ & $\mathrm{PM}_{2.5}$ \\
\hline Boston (USA) & NowAK et al. (2006) & 758 & 5334 & 5334 & 1306 & 3561 & - \\
\hline Urban Areas USA & MulLER/MENDELSOHN (2007) & - & - & - & 1185 & 395 & 2607 \\
\hline Santiago (Chile) & EsCOBEDO et al. (2008) & - & - & - & - & 6436 & - \\
\hline Guangzhou (China) & JIM/CHEN (2008) & - & 138 & - & 138 & - & - \\
\hline Beijing (China) & JIM/CHEN (2009) & - & - & - & 276 & - & - \\
\hline Lanzhou (China) & JIM/CHEN (2009) & - & - & - & 138 & - & - \\
\hline Los Angeles (USA) & MCPHERSON et al. (2011) & - & 6879 & - & 4354 & 8621 & - \\
\hline Toronto (Canada) & Millward/SABiR (2011) & - & 7979 & 7979 & 6051 & 14441 & - \\
\hline Bruges (Belgium) & VANDERMEULEN et al. (2011) & - & - & - & - & 30000 & - \\
\hline Bruges (Belgium) & VANDERMEULEN et al. (2011) & - & - & - & - & 300 & - \\
\hline
\end{tabular}

Source: own compilation 
data is needed to run the valuation model. Hourly pollution concentration data for 2011 is retrieved from the German Federal Environmental Agency (Umweltbundesamt). We use hourly concentrations from all measurement stations within the city boundaries for six pollutants: Carbon monoxide $(\mathrm{CO})$, nitrogen dioxide $\left(\mathrm{NO}_{2}\right)$, ozone $\left(\mathrm{O}_{3}\right)$, sulfur dioxide $\left(\mathrm{SO}_{2}\right)$, particulate matter less than 10 microns $\left(\mathrm{PM}_{10}\right)$ and particulate matter less than 2.5 microns $\left(\mathrm{PM}_{2.5}\right)$. Local hourly weather data for 2011 are obtained through the NOAA National Climatic Data Center, NOAA Radiosonde Observation and the national German Weather Agency (Deutscher Wetterdienst, DWD). A leaf area index (LAI) of $6.0 \mathrm{~m}^{2} / \mathrm{m}^{2}$ is used as an approximation for managed mixed forests in this region (MATYSSEK et al. 2009). Minimum and maximum scenarios are computed according to the level of uncertainty.

i-Tree calculates only for land cover type tree. However, air pollution removal by land cover type grass/herbaceous is very low compared to trees (EsCOBEDO et al. 2008). To prevent double counting, i-Tree creates an adjusted $\mathrm{PM}_{10}$ *, which is $\mathrm{PM}_{10}$ concentration subtracted by $\mathrm{PM}_{2.5}$ concentration (particles between 2.5 and $10 \mathrm{mi}$ crons). To estimate monetary values, i-Tree uses BenMAP (Environmental Benefits Mapping and Analysis Program). BenMAP investigates what kind of health impacts occur due to specific pollution concentrations. Moreover it accounts the generated costs to the health system in relation to local population density (BENMAP 2014). This transfer from the US health system will be explained below, and detailed information about algorithms used in i-Tree can be found in NOWAK et al. (2008), HirABAYASHI et al. (2011), HiRABAYASHI et al. (2012) and NowAK et al. (2013).

Runoff reduction. Different land cover types influence surface runoff. In urban areas land cover type Impervious is one of the most common (e.g. buildings, streets, squares). Precipitation on impervious surfaces is not able to infiltrate into the soil. This water will be collected and transported by a sewage system. To maintain this system, costs may arise. Depending on the specific communal sewage system different kinds of costs occur. In combined systems rainwater and sanitary sewage are transported in the same pipes and treated in a wastewater treatment plant. Urban green spaces enable rainwater to infiltrate into the soil and thereby reduce the amount of surface runoff. Tab. 6 shows case studies which calculate values $\left(€ / \mathrm{m}^{3}\right)$ for runoff reduction in a specific study area. Determining factor for calculated values is the specific situation of the case study and therefore which types of costs exist.

In Munich the sewage system works along the runoff gradient from south to north. This is a beneficial situation because there is no electricity needed to pump the water. In downtown $\mathrm{Mu}$ nich, a combined system for rainwater and sanitary sewage is used, while in peripheral zones, rainwater is locally forced to infiltrate into the soil by a technical drainage system (infiltration trench). This difference is important because in combined systems pipe diameter is based on rainwater during heavy rain events instead of wastewater from households which does not have such high peaks. Munich has $2400 \mathrm{~km}$ of pipes and several underground rainwater storage basins with a volume of $706000 \mathrm{~m}^{3}$ (Münchner Stadtentwässerung 2012).

Only a fraction of precipitation on impervious surfaces runs into the sewage system depending on surface characteristics and climate factors (e.g. temperature, wind) which lead to evaporation. The City of Munich estimates that $70 \%$ of annual precipitation on impervious surfaces runs into the pipes of the sewage system (30\% evaporation) (Münchner Stadtentwässerung 2012). This value corresponds to calculated runoff coef-

Tab. 6: Case studies with values for runoff reduction

\begin{tabular}{lllc} 
Study Area & Author & Type of Costs & Value $\left(€ / \mathrm{m}^{3}\right)$ \\
\hline Nanjing (China) & JiM/CHEN (2009) & Rainwater Storage & 0.23 \\
Los Angeles (USA) & MCPHERSON et al. (2011) & Runoff Purification, Flood Control & 1.50 \\
Toronto (Canada) & MiLLWARD/SABIR (2011) & Runoff Purification & 1.53 \\
Lisbon (Portugal) & SoARES et al. (2011) & Maintenance of Sewage System & 8.28 \\
Beijing (China) & ZHANG et al. (2012) & Runoff Purification & 0.23 \\
Beijing (China) & ZHANG et al. (2012) & Rainwater Storage & 1.78 \\
\hline
\end{tabular}

Source: own compilation 
ficients from various studies (e.g. $80 \%$ for urban impervious surface in ZHANG et al. 2012). The City of Munich imposes fees for rainwater runoff at $1.30 € / \mathrm{m}^{2} / \mathrm{yr}$ (Landeshauptstadt München 2005). This annual fee is based on property size and is paid by the owner. The specific amount of fees results from the costs of the sewage system to the City of Munich. In addition, the city government uses a reference value $(G A B)$ to estimate the proportion of impervious surface on each property. The $G A B$ is an average value which is calculated for each municipal district.

This municipal accounting scheme can be used to monetize the ecosystem service. In Schlosspark Nymphenburg the area size of non-impervious land cover types tree, grass/herbaceous and water is $1565501 \mathrm{~m}^{2}$ (Tab. 1). Together with local experts from city government we developed a scenario to estimate what costs would occur if the Schlosspark Nymphenburg does not exist and could not provide this ecosystem service. In this case, instead of a large urban green space, this area would be characterized by a mixture of residential, commercial/industrial and traffic zones. The $G A B$ of surrounding areas is 0.5 ( $50 \%$ of surface is impervious), which can be used as an approximation for the scenario. In this part of the city a combination of the combined rainwater and sanitary sewage system and the use of infiltration trenches exists. City government tries to increase the percentage of properties which use infiltration trenches. Following advice from local experts we assume that in the area of a developed Schlosspark Nymphenburg $80 \%$ of impervious surfaces would have infiltration trenches and about $20 \%$ would be connected to the sewage system. These assumptions lead to the following valuation model for the ecosystem service runoff reduction:

$$
\sum_{i} S_{i} \times V_{\mathrm{FRR}} \times G A B \times I C=E S_{\mathrm{RR}}
$$

where $S_{i}$ is the area $\left(\mathrm{m}^{2}\right)$ of non-impervious land cover types tree $\left(S_{\mathrm{T}}\right)$, grass/herbaceous $\left(S_{\mathrm{G}}\right)$ and water $\left(S_{\mathrm{W}}\right) ; V_{\mathrm{FRR}}$ is the value of the fee for rainwater runoff $\left(€ / \mathrm{m}^{2} / \mathrm{yr}\right) ; G A B$ is the reference value used by local authorities for average proportion of impervious surface in this municipal district; and $I C$ is the infiltration coefficient which describes the percentage of impervious surfaces which have infiltration trenches.

Groundwater recharge. The ecosystem service groundwater recharge describes the ability of ecosystems to increase the quantity of ground- water. This service does not cover aspects about the quality of groundwater. Urban growth and the increase of impervious surfaces can lower the amounts of groundwater recharge. This change heavily influences the water balance and cycle of urban areas (GöBEL et al. 2007). Various studies have been conducted to analyze the interactions of land use change, groundwater extraction (e. g. public water supply, industrial cooling water supply, irrigation water) and groundwater levels in urban areas (CUTTER 2007; HAASE 2009; LERNER/HARris 2009; e.g. ChOI et al. 2012).

To calculate the amount of groundwater recharge by the Schlosspark Nymphenburg, we use annual precipitation and relevant land cover types. The long-term average annual precipitation in $\mathrm{Mu}$ nich is $0.959 \mathrm{~m} / \mathrm{yr}$ (Landeshauptstadt München 2010). Relevant land cover types are tree and grass/herbaceous since rainwater can infiltrate into the soil from these surfaces $\left(1432982 \mathrm{~m}^{2}\right)$. The precipitation on artificial lakes and streams in the Schlosspark Nymphenburg is directly transported to a connected river and therefore not relevant for groundwater recharge. Only a portion of total precipitation leads to groundwater recharge depending on surface runoff and evapotranspiration. GöBEL et al. (2007) calculate an average annual groundwater recharge of $24 \%$ of annual precipitation for mixed grass and tree vegetation under natural conditions in Germany. Similar approximated values are estimated for the area around Munich (Bundesministerium für Umwelt, Naturschutz und Reaktorsicherheit (BMU) 2000; KöLling/Tomsu 2003) and Minnesota (USA) (ERICKSON/STEFAN 2009).

Because of the importance of groundwater for human settlements, some federal states of Germany charge a fee for the extraction of groundwater. Tab. 7 shows selected federal states and their fees $\left(€ / \mathrm{m}^{3}\right)$ depending on the intended purpose of the extraction. Since Munich does not have fees for groundwater extraction we use values from federal state Baden-Württemberg. This value $\left(0.051 € / \mathrm{m}^{3}\right)$ nearly averages existing fees in Germany, and Baden-Württemberg has comparable groundwater conditions to the region around Munich (Bavaria). The following valuation model is used for ecosystem service groundwater recharge:

$$
S_{i} \times P_{\mathrm{M}} \times G R_{\mathrm{M}} \times V_{\mathrm{FGE}}=E S_{\mathrm{GR} i}
$$

where $S_{i}$ is the area $\left(\mathrm{m}^{2}\right)$ of land cover type $i ; P_{\mathrm{M}}$ is the long-term average annual precipitation in 
Tab. 7: Legal regulations of groundwater extraction in different federal states in Germany

\begin{tabular}{llc} 
Federal State & Intended Purpose & Value $\left(€ / \mathrm{m}^{3}\right)$ \\
\hline $\begin{array}{l}\text { Baden-Württemberg } \\
\text { (Landtag von Baden- }\end{array}$ & All-Purpose & 0.051 \\
$\begin{array}{l}\text { Württemberg 2010) } \\
\text { Public Water Supply }\end{array}$ & 0.128 \\
$\begin{array}{l}\text { Hesse } \\
\text { (Hessischer }\end{array}$ & $\begin{array}{l}\text { Industrial Cooling } \\
\text { Landtag 1992) }\end{array}$ & 0.281 \\
& Water Supply & \\
\hline & Industrial Water & 0.230 \\
Saxony & Supply \\
(Sächsischer & Public Water Supply & 0.015 \\
Landtag 2012) & Industrial Cooling & 0.076 \\
& Water Supply & \\
\hline
\end{tabular}

Source: own compilation

Munich (m/yr); $G R_{\mathrm{M}}$ is the rate of groundwater recharge in relation to precipitation in the area of Munich; and $V_{\mathrm{FGE}}$ is the value of the fee for groundwater extraction $\left(€ / \mathrm{m}^{3}\right)$.

\section{Results}

The output of i-Tree Eco for air pollution removal by Schlosspark Nymphenburg in 2011 is shown in Tab. 8. Pollution removal per unit tree cover $\left(\mathrm{g} / \mathrm{m}^{2}\right)$ ranges from $0.2 \mathrm{~g} / \mathrm{m}^{2}$ for $\mathrm{CO}$ to $4.1 \mathrm{~g} / \mathrm{m}^{2}$ for $\mathrm{O}_{3}$. According to this, annual total amounts (t) range from $0.28 \mathrm{t}$ for $\mathrm{CO}$ to $4.92 \mathrm{t}$ for $\mathrm{O}_{3}$. Value per ton removed $(€ / \mathrm{t})$ varies strongly from $412 € / \mathrm{t}$ for $\mathrm{SO}_{2}$ and $998 € / \mathrm{t}$ for $\mathrm{NO}_{2}$ to $475429 € / \mathrm{t}$ for $\mathrm{PM}_{2.5}$. Total value of pollution removal is characterized by low values for $\mathrm{SO}_{2}$ $(180 €)$ and $\mathrm{CO}(310 €)$ and a very high value for $\mathrm{PM}_{2.5}$ (321 $\left.810 €\right)$. Total value for all pollutants is $392170 €$ with $65590 €$ for the minimum and $785310 €$ for the maximum scenario.

Using the valuation models presented in section 2 , calculated monetary values $(€ / \mathrm{yr})$ of ecosystem services for Schlosspark Nymphenburg by land cover type are shown in Tab. 9. In addition to values for carbon sequestration $(€ / y r)$, values between parentheses are for carbon storage $(€)$ and land cover types Tree (673 $316 €$ ) and Grass/ Herbaceous (2211€).

Tab. 8: Annual amounts and monetized values of air pollution removal for Schlosspark Nymphenburg

\begin{tabular}{lccccrrrr}
$\begin{array}{l}\text { Air } \\
\text { Pollutant }\end{array}$ & $\begin{array}{c}\text { Amount per Area } \\
\left(\mathrm{g} / \mathrm{m}^{2}\right)\end{array}$ & Total & $\begin{array}{c}\text { Amount }(\mathrm{t}) \\
\text { Min }\end{array}$ & Max & $\begin{array}{r}\text { Value per Ton } \\
(€ / \mathrm{t})\end{array}$ & Total & Min & Max \\
\hline $\mathrm{CO}$ & 0.2 & 0.28 & 0.28 & 0.28 & 1116 & 310 & 310 & 310 \\
$\mathrm{NO}_{2}$ & 3.1 & 3.67 & 1.38 & 4.83 & 998 & 3660 & 1380 & 4820 \\
$\mathrm{O}_{3}$ & 4.1 & 4.92 & 1.17 & 6.75 & 8313 & 40920 & 9700 & 56120 \\
$\mathrm{SO}_{2}$ & 0.4 & 0.44 & 0.22 & 0.81 & 412 & 180 & 90 & 340 \\
$\mathrm{PM}_{10}{ }^{*}$ & 4.0 & 4.82 & 2.05 & 7.14 & 5252 & 25290 & 10790 & 37490 \\
$\mathrm{PM}_{2.5}$ & 0.6 & 0.68 & 0.09 & 1.44 & 475429 & 321810 & 43320 & 686230 \\
\hline Total & - & 14.81 & 5.19 & 21.25 & - & 392170 & 65590 & 785310 \\
\hline
\end{tabular}

Source: own calculation

Tab. 9: Monetized values of ecosystem services for Schlosspark Nymphenburg by land cover types $(€ / \mathrm{yr})$

\begin{tabular}{lccccr}
$\begin{array}{c}\text { Ecosystem Service } \\
\text { Land Cover Type }\end{array}$ & $\begin{array}{c}\text { Carbon Sequestration } \\
\text { and Storage }\end{array}$ & $\begin{array}{c}\text { Air Pollution } \\
\text { Removal }\end{array}$ & $\begin{array}{c}\text { Runoff } \\
\text { Reduction }\end{array}$ & $\begin{array}{c}\text { Groundwater } \\
\text { Recharge }\end{array}$ & Total \\
\hline Tree & 15080 & 392170 & 155824 & 14070 & 577144 \\
Grass/Herbaceous & $(673316)$ & & & & \\
& $(2211)$ & 0 & 30464 & 2751 & 33215 \\
Water & 0 & 0 & 17227 & 0 & 17227 \\
Impervious & 0 & 0 & 0 & 0 & 0 \\
\hline Total & 15080 & 392170 & 203515 & 16821 & 627586 \\
\hline
\end{tabular}

Source: own calculation 
Monetized values per year $(€ / \mathrm{yr})$ range from $0 € / \mathrm{yr}$ to $392170 € / \mathrm{yr}$ for ecosystem service air pollution removal and land cover type Tree. Values for land cover type Impervious are $0 € / \mathrm{yr}$ for each ecosystem service and therefore this land cover type does not contribute to generated services by the Schlosspark Nymphenburg. Tree has the highest total value $(577144 € / \mathrm{yr})$ of all land cover types, followed by grass/herbaceous $(33215 € / \mathrm{yr})$ and water $(17227 € / \mathrm{yr})$. Since these values are not per square meter, this result reflects the area size of different land cover types in Schlosspark Nymphenburg (Tab. 1). Total value of ecosystem services is highest for air pollution removal $(392170 € / \mathrm{yr})$ and runoff reduction $(203515 € / \mathrm{yr})$. Overall total value for all calculated ecosystem services by the Schlosspark Nymphenburg is $627586 € / y r$.

In addition to services, urban green spaces also create costs. Together with the administration of Schlosspark Nymphenburg, we identified the annual costs for maintaining the area of the case study. Different types of costs in 2011 are shown in Tab. 10. Total maintenance costs of Schlosspark Nymphenburg in 2011 are $1150000 €$. In relation to calculated services, this shows that there is a spread of $522414 € / \mathrm{yr}$ between annual ecosystem services and maintenance costs of this urban green space.

Tab. 10: Administrative costs of Schlosspark Nymphenburg 2011

Type of Costs Costs $(€ / \mathrm{yr})$

Material Costs:

- Equipment and Machines

30000

- Maintenance of Vehicles, Equipment, 130000 Safety Equipment etc.

- Maintenance of Immovable Assets

140000

(Land, Pathway Surfaces, Water

Bodies, Bank Reinforcement etc.)

Labor Costs for 28 Workers

(Gardeners, Supervisors etc.)

\begin{tabular}{ll}
\hline Total & 1150000
\end{tabular}

Source: own compilation

\section{Discussion}

When monetizing ecosystem services, it is very important to consider the perspective of who receives the service. Different stakeholders profit from different ecosystem services. Most services in this case study are received by the local pop- ulation. People in and around Munich benefit from services like air pollution removal (directly) or runoff reduction (indirectly; lower costs to the City of Munich means lower taxes). Several issues concerning the perspective and other topics occur during the valuation of the ecosystem services by Schlosspark Nymphenburg:

Regarding carbon sequestration and storage, we choose the European Union Emissions Trading Scheme (EU ETS) for our valuation method. Mitigation of greenhouse gas emissions at a local level does not affect local population. However, in a global context this service is also received by local populations. EU ETS has some advantages compared to social cost approaches. Social cost approaches are not able to summarize all generated costs and are very difficult to transfer to other case studies. In emission trading systems, the price of one emission allowance results from supply and demand of traders. This price adjusts with time depending on several factors (e.g. innovations, economic growth and amount of tradable allowances provided by the government). We do not calculate carbon storage for land cover type Water because the water in Schlosspark Nymphenburg is taken from a river, and the artificial lakes and streams in Schlosspark Nymphenburg do not have aquatic plants. Schlosspark Nymphenburg sequesters carbon dioxide because it is a growing forest (since it has become part of Natura 2000).

Regarding air pollution removal, the use of BenMAP (within i-Tree) implies that we calculate costs based on the US health system. The transfer to the German health system can only be seen as an approximation since many differences exist between these two national health systems. Nevertheless, there are also many similarities concerning the costs of medical treatment created by diseases. Similar drugs are developed from same pharmaceutical companies, doctors get their education from cooperating universities and medical technology (e.g. X-ray, magnetic resonance tomograph) is produced by the same companies and creates similar costs. Results for air pollution removal (Tab. 8) show very low values per ton $(€ / t)$ for $\mathrm{NO}_{2}$ and $\mathrm{SO}_{2}$ and a very high value per ton for $\mathrm{PM}_{2.5}(475429 € / \mathrm{t})$. This difference is because BenMAP considers some health impacts (e.g. mortality/value of statistical life), which are affected by all three pollutants, primarily caused by $\mathrm{PM}_{2.5}$. 
Regarding runoff reduction, we use a modified valuation method to validate the results. Costs of the sewage system can be separated into fixed and variable costs. The City of Munich calculates that $20 \%$ or less of total costs are variable costs. As an alternative scenario we assume an attempt of the city to convert impervious surface to an urban green space. The amount of reduced costs can be calculated by multiplying area size and variable costs (percentage of fee for rainwater runoff) $\left(\max .0 .2 \times 1.30 € / \mathrm{m}^{2} / \mathrm{yr} \leq 0.26 € / \mathrm{m}^{2} / \mathrm{yr}\right)$. The result is slightly above our first scenario estimates (see section 'Runoff reduction') and therefore supports calculated values. To compare results of runoff reduction to previous case studies (Tab. 6), values can be converted to costs per cubic meter $\left(€ / \mathrm{m}^{3}\right)$. Average annual precipitation $(0.959 \mathrm{~m} / \mathrm{yr})$ multiplied by runoff coefficient (70\%) equals $0.671 \mathrm{~m}^{3}$ rainwater per square meter per year $\left(1 \mathrm{~m} \triangleq 1 \mathrm{~m}^{3} / \mathrm{m}^{2}\right)$. Considering fees for rainwater runoff $\left(1.30 € / \mathrm{m}^{2} / \mathrm{yr}\right)$ this leads to costs for water that runs into the sewage system of $1.94 € / \mathrm{m}^{3}\left(1.30 € / 0.671 \mathrm{~m}^{3}\right)$. Compared to values in Tab. 6 , this is the second highest value but still in the medium range of previous results.

Regarding the total of all ecosystem services (Tab. 9), the spread between total value of ecosystem services and maintenance costs (Tab. 10) does not mean that Schlosspark Nymphenburg has a negative balance. Services are not the same as revenues and are difficult to compare to costs. Even if services are perceived as revenues, one could argue that the maintenance of this urban green space is not very expensive because calculated services reduce costs by more than $50 \%$. Annual ecosystem services could also be compared to opportunity costs (value of an alternative use of the park area). However, it is obvious that revenues from residential buildings and commercial property (e.g. shopping center) are much higher than ecosystem services calculated in this study. In addition, numerous ecosystem services are not calculated in this analysis.

For the interpretation of monetized ecosystem services in this study, several aspects have to be considered. First of all, our global market-based system asks for quantified and monetized numbers and parameters. Calculated values for ecosystem services are only approximations. The aim of these calculations has to be to improve methods and values and to limit uncertainty. By calculating such values, several ethical and moral questions arise. For example, the term 'commodification' describes the transformation of parts of nature to market goods. This transformation implies the application of market principles and that environmental goods can be traded and substituted. Establishment of economic incentives and utilitarian logic may lead to changes in motivations for protecting the environment. This change could prevent non-economic motivations and increase competition between different conservation projects.

In addition, several technical issues arise while quantifying ecosystem services. Ecosystems do not follow national borders. For this reason, it might be necessary to use different currencies to assess ecosystem services. The concept of purchasing power parity explains the phenomenon that using a given currency exchange rate, the same amount of money can buy different amounts of goods in different countries or regions. Therefore methods like benefit transfer produce only approximations of 'real' values, and the comparison of ecosystem service values between countries with different currencies is limited. Furthermore, exchange rates change over time. This means that calculations need to be adjusted regularly. Even if calculations are done exclusively within the borders of one country, inflation leads to the necessity of regular adjustments. In this study, we used inflationadjusted data whenever possible. The economic concept of time preference and time discounting might play a role for some services (e.g. carbon storage) when people discount future benefits.

A fundamental aspect of this kind of valuation study is that it is not possible to calculate a real total value of an ecosystem. In this study, we selected 4 ecosystem services (we calculated additional services like water purification and flood protection but could not evaluate positive values). Many more ecosystem services do exist, some were quantified in previous studies (see TEEB 2010) and some of them are provided by the Schlosspark Nymphenburg (especially cultural services). We decided to analyze as many services as possible, instead of a very detailed analysis of only one service. Still, total value of all services would be much higher than the value we calculated $(627586 € / \mathrm{yr})$. In our opinion, this kind of valuation study should not even try to quantify an entire ecosystem. It is about valuing specific, previously defined services from the perspective of a user of this service. It is not possible to monetize one tree but it is possible to monetize some specific services of this tree from a defined perspective. 
Accounting of environmental assets and calculation of ecosystem services creates possibilities for the misuse of these numbers. It could be argued that environmental goods can be substituted by economic goods of the same value. If calculated values are perceived and interpreted as total values, this would lead to wrong assumptions about substitution of the environment. Therefore it is very important to clearly explain which information these numbers contain, to be transparent about the methods and to communicate this information to the audience.

\section{Conclusion}

Valuation of ecosystem services involves application-oriented research with the aim of solving problems. Disadvantages of the valuation can be tolerated as long as advantages are predominant. The balance of advantages and disadvantages depends upon the quality of the calculated values and the way of using these values. For this reason, it is very important to communicate what kind of information these values contain.

Results can support local stakeholders (e.g. city government) with more information regarding future implications of land use changes. During the decision process it is important to have as much information as possible about the consequences of land cover changes. In addition, findings give information that can be used by local decision makers to increase ecosystem services provided by urban green spaces (different values of different land cover types). - This case study demonstrates that even conservative calculations about the ecosystem service values lead to substantial monetary values. The Schlosspark Nymphenburg has a significant positive influence to the local population of Munich.

\section{Acknowledgements}

We would like to thank the administration of the Schlosspark Nymphenburg (Bayerische Verwaltung der staatlichen Schlösser, Gärten und Seen) for their cooperation and the Elite Network of Bavaria for funding this project.

\section{References}

Atkinson, G. / Gundimeda, H. (2006): Accounting for India's forest wealth. In: Ecological Economics, (59)4, $462-476$.
Baumgardner, D. / Varela, S. / Escobedo, F. J. / Chacalo, A. / OCHOA, C. (2012): The role of a peri-urban forest on air quality improvement in the Mexico City megalopolis. In: Environmental Pollution, 163, 174-183.

Bayerische Forstverwaltung (Hrsg.) (2012): Managementplan für das FFH-Gebiet Nymphenburger Park mit Allee und Kapuzinerhölzl (DE 7834-301). Ebersberg.

Bayerische Vermessungsverwaltung (Hrsg.) (2012): GeodatenOnline Rasterdaten DOP20. München.

Bayerische Vermessungsverwaltung (Hrsg.) (2013): GeodatenOnline Rasterdaten DTK50. München.

BENMAP (2014): Environmental benefits mapping and analysis Program. Internet: http://www.epa.gov/airquality/ benmap/index.html, 1.8.2014.

Boisvert, V. / Méral, P. / Froger, G. (2013): Market-based instruments for ecosystem services. Institutional innovation or renovation? In: Society \& Natural Resources, (26)10, 1122-1136.

Bolund, P. / Hunhammar, S. (1999): Ecosystem services in urban areas. In: Ecological Economics, (29)2, 293-301.

Boyd, J./BANZHAF, S. (2007): What are ecosystem services? The need for standardized environmental accounting units. In: Ecological Economics, (63)2-3, 616-626.

Bundesministerium für Umwelt, Naturschutz und Reaktorsicherheit (BMU) (Hrsg.) (2000): Hydrologischer Atlas von Deutschland. Berlin.

Burschel, P. (1995): Forests, forestry and global ecology. In: Forstwissenschaftliches Centralblatt, (114)2, 80-96.

Choi, W. / Galasinski, U. / Cho, S.-J. / Hwang, C.-s. (2012): A spatiotemporal analysis of groundwater level changes in relation to urban growth and groundwater recharge potential for Waukesha County, Wisconsin. In: Geographical Analysis, (44)3, 219-234.

Costanza, R. / Cmberland, J. H. / Daly, H. E. / Godland, R. J. / NORGAard, R. B. / EsER, T. W. (2001): Einführung in die ökologische Ökonomik. Stuttgart.

Costanza, R. / Darge, R. / De Groot, R. / Farber, S. / Grasso, M. / Hannon, B. / Limburg, K. / Naeem, S. / Oneill, R. V. / Paruelo, J. / Raskin, R. G. / Sutton, P. / van DEN BELT, M. (1997): The value of the world's ecosystem services and natural capital. In: Nature, (387)6630, 253260.

CutTER, W.B. (2007): Valuing groundwater recharge in an urban context. In: Land Economics, (83)2, 234-252.

DAILY, G. C. (Ed.) (1997): Nature's services. Societal dependence on natural ecosystems. Washington, DC.

Davies, Z. G. / Edmondson, J. L. / Heinemeyer, A. / Leake, J.R. / GAston, K.J. (2011): Mapping an urban ecosystem service: Quantifying above-ground carbon storage at a city-wide scale. In: Journal of Applied Ecology, (48)5, $1125-1134$.

Dieter, M. / ElsAsSER, P. (2002): Carbon stocks and carbon stock changes in the tree biomass of Germany's forests. In: Forstwissenschaftliches Centralblatt, (121)4, 195-210.

Dobis, C. / Escobedo, F. J. / ZipPeRER, W. C. (2011): A framework for developing urban forest ecosystem services and goods indicators. In: Landscape and Urban Planning, (99) 3-4, 196-206. 
Energy Exchange Austria (EXAA) (2014): Historische Marktdaten EU Emission Allowances. Internet: http://www. exaa.at/de/marktdaten/historische-daten, 5.4.2014.

ERICKSON, T. O./Stefan, H.G. (2009): Natural groundwater recharge response to urbanization: Vermillion River watershed, Minnesota. In: Journal of Water Resources Planning and Management, (135)6, 512-520.

Escobedo, F. J. / NowAK, D. J. (2009): Spatial heterogeneity and air pollution removal by an urban forest. In: Landscape and Urban Planning, (90)3-4, 102-110.

Escobedo, F. J. / Wagner, J. E. / NowAK, D. J. / DE LA MaZA, C. L. / Rodriguez, M. / Crane, D. E. (2008): Analyzing the cost effectiveness of Santiago, Chile's policy of using urban forests to improve air quality. In: Journal of Environmental Management, (86)1, 148-157.

FARLEY, J. (2012): Ecosystem services: The economics debate. In: Ecosystem Services, (1)1, 40-49.

Fisher, B. / Turner, R. K. / Morling, P. (2009): Defining and classifying ecosystem services for decision making. In: Ecological Economics, (68)3, 643-653.

GöBel, P. / Coldwey, W. G. / Dierkes, C. / Kories, H. / MesSER, J./ MEISSNER, E. (2007): Impacts of green roofs and rain water use on the water balance and groundwater levels in urban areas. In: Grundwasser, (12)3, 189-200.

Gómez-Baggethun, E. / Kelemen, E. / Martín-LóPez, B. / Palomo, I. / Montes, C. (2013): Scale misfit in ecosystem service governance as a source of environmental conflict. In: Society \& Natural Resources, (26)1, 1202-1216.

DE Groot, R./Wilson, M.A. / Boumans, R. M.J. (2002): A typology for the classification, description and valuation of ecosystem functions, goods and services. In: Ecological Economics, (41)3, 393-408.

Gundimeda, H. / Sukhdev, P. / Sinha, R.K. / Sanyal, S. (2007): Natural resource accounting for Indian states. Illustrating the case of forest resources. In: Ecological Economics, (61)4, 635-649.

HAASE, D. (2009): Effects of urbanisation on the water balance. A long-term trajectory. In: Environmental Impact Assessment Review, (29)4, 211-219.

HAuck, J. / GÖrG, C. / VARJopuro, R. / RARAmäKi, O. / JAX, K. (2013): Benefits and limitations of the ecosystem services concept in environmental policy and decision making: Some stakeholder perspectives. In: Environmental Science \& Policy, 25, 13-21.

Hessischer Landtag (Hrsg.) (1992): Hessisches Grundwasserabgabengesetz (HGruwAG). Wiesbaden.

Hirabayashi, S. / Kroll, C. N. / NowaK, D. J. (2011): Component-based development and sensitivity analyses of an air pollutant dry deposition model. In: Environmental Modelling and Software, (26)6, 804-816.

Hirabayashi, S. / Kroll, C.N. / NowaK, D. J. (2012): Development of a distributed air pollutant dry deposition modeling framework. In: Environmental Pollution, 171, 9-17.

Jenkins, W.A. / Murray, B. C. / Kramer, R.A. / FAulKner, S.P. (2010): Valuing ecosystem services from wetlands restoration in the Mississippi Alluvial Valley. In: Ecological Economics, (69)5, 1051-1061.
JiM, C.Y. / Chen, W.Y. (2006): Perception and attitude of residents toward urban green spaces in Guangzhou (China). In: Environmental Management, (38)3, 338-349.

JiM, C. Y. / CHEN, W. Y. (2008): Assessing the ecosystem service of air pollutant removal by urban trees in Guangzhou (China). In: Journal of Environmental Management, (88)4, 665-676.

JiM, C. Y. / CHEN, W.Y. (2009): Ecosystem services and valuation of urban forests in China. In: Cities, (26)4, 187-194.

Kölling, C. / Tomsu, C. (2003): Grundwassermodell östliche Münchner Schotterebene. In: Umweltreport der Stadt München 2003. München, 59-66.

Kottek, M. / Grieser, J. / Beck, C. / Rudolf, B. / Rubel, F. (2006): World map of the Köppen-Geiger climate classification updated. In: Meteorologische Zeitschrift, (15)3, 259-263.

Landeshauptstadt München (Hrsg.) (2005): Satzung über Abgaben beim Anschluss an städtische Kanäle und für die Benutzung der städtischen Entwässerungseinrichtung (Entwässerungsabgabensatzung, EAS). München.

Landeshauptstadt München (Hrsg.) (2010): Statistisches Jahrbuch 2010. München.

Landtag von Baden-Württemberg (Hrsg.) (2010): Gesetz zur Änderung der Vorschriften über das Wasserentnahmeentgelt. Stuttgart.

LERnER，D.N./HARris，B. (2009): The relationship between land use and groundwater resources and quality. In: Land Use Policy, 26, S265-S273.

Luck, G. W. / Chan, K. M.A. / Eser, U. / Gomez-BAGgeThun, E. / Matzdorf, B. / Norton, B. / Potschin, M. B. (2012): Ethical considerations in on-ground applications of the ecosystem services concept. In: BioScience, (62)12, $1020-1029$.

Matero, J. / SAASTAMOINEN, O. (2007): In search of marginal environmental valuations. Ecosystem services in Finnish forest accounting. In: Ecological Economics, (61)1, 101-114.

Matyssek, R. / Wieser, G. / Patzner, K. / Blaschke, H./ HÄBERLE, K.H. (2009): Transpiration of forest trees and stands at different altitude: Consistencies rather than contrasts? In: European Journal of Forest Research, (128)6, 579-596.

McPherson, E. G. / Simpson, J. R. / Xiao, Q. / Wu, C. (2011): Million trees Los Angeles canopy cover and benefit assessment. In: Landscape and Urban Planning, (99)1, 40-50.

Millennium Ecosystem Assessment (MA) (Ed.) (2005): Ecosystems and human well-being: Synthesis. Washington, DC.

Millward, A.A./SABIR, S. (2011): Benefits of a forested urban park: What is the value of Allan Gardens to the city of Toronto, Canada? In: Landscape and Urban Planning, (100)3, 177-188.

Muller, N.Z./Mendelsohn, R. (2007): Measuring the damages of air pollution in the United States. In: Journal of Environmental Economics and Management, (54)1, 1-14.

Münchner Stadtentwässerung (Hrsg.) (2012): Geschäftsbericht 2011 Nachhaltigkeit. München. 
Muradian, R. (2013): Payments for ecosystem services as incentives for collective action. In: Society \& Natural Resources, (26)10, 1155-1169.

NowAK, D. J. / CRANE, D. E. (2002): Carbon storage and sequestration by urban trees in the USA. In: Environmental Pollution, (116)3, 381-389.

Nowak, D. J. / Crane, D. E. / Stevens, J.C. (2006): Air pollution removal by urban trees and shrubs in the United States. In: Urban Forestry \& Urban Greening, (4)3-4, 115123.

Nowak, D. J./ Crane, D. E. / Stevens, J.C. / Hoehn, R.E. / WALTON, J. T. / BOND, J. (2008): A ground-based method of assessing urban forest structure and ecosystem services. In: Arboriculture and Urban Forestry, (34)6, 347-358.

NowaK, D. J./ Greenfield, E. J. (2012): Tree and impervious cover change in US cities. In: Urban Forestry \& Urban Greening, (11)1, 21-30.

Nowak, D. J. / Hirabayashi, S. / Bodine, A. / Hoehn, R. (2013): Modeled $\mathrm{PM}_{2.5}$ removal by trees in ten U.S. cities and associated health effects. In: Environmental Pollution, 178, 395-402.

Perman, R. (2003): Natural resource and environmental economics. Harlow.

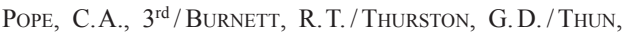
M.J. / Calle, E. E. / Krewski, D. / GodlesKi, J. J. (2004): Cardiovascular mortality and long-term exposure to particulate air pollution: Epidemiological evidence of general pathophysiological pathways of disease. In: Circulation, (109) 1, 71-77.

Rogall, H. (2008): Ökologische Ökonomie. Eine Einführung. Wiesbaden.

Sächsischer Landtag (Hrsg.) (2012): Sächsisches Wassergesetz (SächsWG). Dresden.

SCHRÖDER, W. / SCHMIDT, G. / PESCH, R. (2009): Großräumige Regionalisierung der Kohlenstoffbindung in Wäldern Nordrhein-Westfalens. In: Umweltwissenschaften und Schadstoff-Forschung, (21)6, 516-526.

Siebert, H. (2008): Economics of the environment. Theory and policy. Berlin.
SMith, W.H. (1990): Air pollution and forests. Interactions between air contaminants and forest ecosystems. New York. SoAres, A. L. / Rego, F. C. / McPherson, E. G. / Simpson, J. R. / PEPER, P. J. / XIAO, Q. (2011): Benefits and costs of street trees in Lisbon, Portugal. In: Urban Forestry \& Urban Greening, (10)2, 69-78.

Strohbach, M. W. / HaAse, D. (2012): Above-ground carbon storage by urban trees in Leipzig, Germany. Analysis of patterns in a European city. In: Landscape and Urban Planning, (104)1, 95-104.

Tallis, M. / Taylor, G. / Sinnett, D. / Freer-Smith, P. (2011): Estimating the removal of atmospheric particulate pollution by the urban tree canopy of London, under current and future environments. In: Landscape and Urban Planning, (103)2, 129-138.

TEEB (Ed.) (2010): The economics of ecosystems and biodiversity. Ecological and Economic Foundations. London.

Umweltbundesamt (Hrsg.) (2013): Luftqualität 2012. Vorläufige Auswertung. Dessau.

VAndermeulen, V. / Verspecht, A. / Vermeire, B. / Van Huylenbroek, G. / Gellynck, X. (2011): The use of economic valuation to create public support for green infrastructure investments in urban areas. In: Landscape and Urban Planning, (103)2, 198-206.

WAINGER, L. / MAZzOTTA, M. (2011): Realizing the potential of ecosystem services. A framework for relating ecological changes to economic benefits. In: Environmental Management, (48)4, 710-733.

Wang, X. / Chen, W. / Zhang, L. / Jin, D. / Lu, C. (2010): Estimating the ecosystem service losses from proposed land reclamation projects: A case study in Xiamen. In: Ecological Economics, (69)12, 2549-2556.

World Bank (2014): PPP conversion factor, GDP (LCU per international \$). Internet: http://data.worldbank.org/indicator/PA.NUS.PPP, 1.8.2014.

Zhang, B. / XiE, G. / Zhang, C. / Zhang, J. (2012): The economic benefits of rainwater-runoff reduction by urban green spaces. A case study in Beijing, China. In: Journal of Environmental Management, 100, 65-71. 